Giorgio Sanguinetti

\title{
A Partimento in Classical Sonata Form by Giacomo Tritto
}

Giacomo Tritto (*Altamura I733; †Naples I824) was a prolific, albeit not tremendously successful, opera composer. In his remarkably long life, he wrote more than fifty operas, mostly comic operas - a lesser genre in late eighteenth-century Naples. Today, his operatic output is remembered mainly because of Il convitato di pietra, a comic opera staged at the Teatro de' Fiorentini in Naples in 1783 , five years earlier than Mozart's Don Gio-

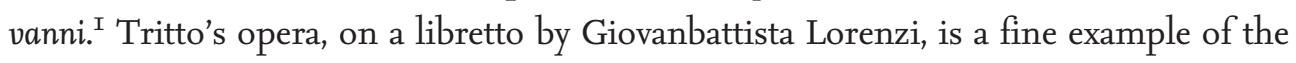
comic side of the Don Giovanni myth and has been recently restaged at the Teatro Verdi in Pisa in the season 2015/16.

Tritto was also one of the most influential Neapolitan teachers of his age. When the two surviving conservatories of the original four, Sant'Onofrio and the Pietà dei Turchini, merged in 1806 into a new Collegio di Musica, instead of a single director, Giuseppe Bonaparte chose Tritto along with Fedele Fenaroli and Giovanni Paisiello to form the so-called Triumvirato - a board of governors - that lasted until I8I3, when Niccolò Zingarelli became the sole governor. Tritto achieved the highest honour through all the stages of his long career. He entered the Conservatorio della Pietà dei Turchini in I746, where he was a student of Pasquale Cafaro and Nicola Sala. ${ }^{2}$ In 1759 he became "maestrino" (teaching assistant) of Cafaro and in 1785 "secondo maestro straordinario" in the same Conservatorio, where in 1799 he became full professor of counterpoint and composition. ${ }^{3}$

1 The position of Tritto's opera as a precursor of Mozart's Don Giovanni has attracted a considerable size of musicological attention. See Stefan Kunze: Don Giovanni vor Mozart. Die Tradition der Don Giovanni-Opern im italienischen Buffa-Theater des I8. Jahrhunderts, München I972; Nino Pirrotta: Don Giovanni in musica. Dall' "Empio punito" a Mozart, Venezia 1999; Daniel Brandenburg: Giacomo Tritto. Il convitato di pietra in Napoli e il teatro musicale in Europa tra Sette e Ottocento, in: Studi in onore di Friedrich Lippman, ed. by Bianca Maria Antolini and Wolfgang Witzenmann, Firenze I993, pp. I45-I74; and Friedrich Lippmann: Vincenzo Fabrizi im Verhältnis zu Giacomo Tritto und Giuseppe Gazzaniga. Sein Convitato di pietra, Rom 1787 , in: Musica come pensiero e azione. Studi in onore di Guido Salvetti, ed. by Marina Vaccarini, Maria Grazia Sità and Andrea Estero, Lucca 2014, pp. I25-I45.

2 According to Francesco Florimo: Cenno storico sulla scuola musicale di Napoli, Vol. I, Naples r869, p. 57I.

3 The first biography of Tritto is contained in Carlo Antonio de Rosa, marquis of Villarosa: Memorie dei Compositori di Musica del Regno di Napoli, Naples I840. A few years later, in I844, Adrien de la Fage published a biographical sketch in Miscellanées musicales, Paris r844, pp. I73-I85. Fétis included Tritto in his Biographie universelle des musiciens (Paris I864) drawing his information from 
As a student of Sala and Cafaro, Tritto was a Leista - a follower of the tradition originating with Leonardo Leo (I694-I744). At the end of the eighteenth century, the Leisti were a minority, the majority of teachers in Naples being Durantisti - followers of Francesco Durante (I684-I755), the other great maestro (together with Leo) of the golden age of the Neapolitan conservatories. 4

According to Francesco Florimo (who was his student), Tritto was a great admirer of Nicola Sala's counterpoint treatise: "[Tritto] studied and carefully pondered the Regole di contrappunto pratico, in those times not even printed, and became such an ardent admirer of them that he elected them, in his opinion, to be the surest and easiest guide and adopted them as a textbook throughout all his long teaching career."5 Florimo stated that Tritto had a "crowd" of students: among them Ercole Paganini, Giuseppe Farinelli, Ferdinando Orlandi, Gaspare Spontini, and Pietro Raimondi. ${ }^{6}$ Other students, such as Nicola Manfroce, Saverio Mercadante, Carlo Conti and Vincenzo Bellini, began their studies with the Leista Tritto but later continued with the Durantista Zingarelli. Florimo was, of course, a special student of Tritto's. At a certain point, Florimo wanted to move from Tritto's class to that of his rival, Zingarelli. Florimo diplomatically put forward a fellow student, Carlo Conti, to act as ambassador to Tritto and make his request, but the reaction of the master was surprisingly benevolent. Smiling, he said: "I am glad - actually, I approve of your move to Zingarelli's class. Although music is one and only one, knowing both schools will surely benefit you. Whenever you want any advice from me, please come, and I will always be more than willing to help you."

Towards the end of his life, Tritto managed to publish two theoretical works: Partimenti e regole generali (Partimenti and General Rules) and Scuola di contrappunto (School of

Villarosa and De la Fage. In the twentieth century, biographical sketches of Tritto appeared in Carlo Schmidl: Dizionario universale dei musicisti, Milan r926-I929; and Giacomo De Napoli: La triade altamurana, Altamura I932. See also Valentina Rossi: Giacomo Tritto, un musicista napoletano del 'joo. Primo tentativo di ricognizione sulle fonti e sull'opera, Diss. Naples: University Federico II, I989/90.

4 For a fresh look on the Leisti versus Durantisti controversy see Peter van Tour: Counterpoint and Partimento. Methods of Teaching Composition in Late Eighteenth-Century Naples, Uppsala 2015.

5 "Quindi passò sotto la direzione di Nicola Sala, e studiò e meditò accuratamente le Regole di contrappunto pratico, allora non peranco stampate, e ne divenne talmente passionato ammiratore, che le prescelse, com'egli opinava, a guida più facile e più sicura, e le adottò per tutto il tempo del suo lungo insegnamento." Francesco Florimo: La scuola musicale di Napoli e i suoi conservatorii, Vol.3, Naples I882, p. 49.

6 Ibid., p.50.

7 "Son contento, anzi approvo che andiate da Zingarelli, e quentunque la musica non sia una, pure il conoscere le due scuole non potrà che recarvi vantaggio; quando vi piacerà avere qualche mia lezione, venite, e mi troverete sempre prontissimo a darvene." Ibid., p.50. 
Counterpoint). ${ }^{8}$ Tritto was eighty-three then, and the king of Naples Ferdinand I (formerly Ferdinand IV), as a sign of admiration and esteem, covered the expenses for the publication of the two treatises. The dedication of both works to Ferdinand I (taken by Ferdinand IV in I8I6 when he restored his kingdom for the second time and annexed Sicily to Naples in the new "Kingdom of the two Sicilies") is a demonstration of Tritto's conservative position, both politically and artistically. Both works were published by Ferdinando Artaria, a member of the same Artaria family that dominated the musical printing business in Vienna during Beethoven's life.

As often happens with the Neapolitan maestri, Partimenti e regole generali shows a mixture of conservative and modern taste. As a Leista Tritto favoured a dense, intricate counterpoint, but, at the same time, he was open to modern tendencies: in fact, he was perhaps the only master who wrote partimenti in Classical sonata form. ${ }^{9} \mathrm{I}$ have discussed elsewhere some idiosyncrasies of Tritto's approach to partimento teaching, such as his treatment of cadences (he lists four types instead of the usual three) and his symmetrical version of the rule of the octave, both probably being tokens of his Leista lineage. ${ }^{\text {TO }}$ Another Leista feature is the use of a slur above several bass notes to indicate the persistence of the same chord, a notational device already used by his teacher Sala. ${ }^{\text {II }}$

The main bulk of Partimenti e regole generali consists of 24 Lezzioni and I2 fugues, all notated as partimenti, in increasing order of difficulty. The notational technique strictly follows the complexity of each individual partimento. The first Lezzioni are all written as figured basses and insist on the basic rules of partimento playing: cadences, rules of the octave, syncopations, bass motions and the like. With Lezzione 8 the tenor clef enters, and in Lezzione ro the exchange between tenor and bass clef takes place every bar, thus signalling a multilayered texture and strongly implying the usage of imitation. With Lezzione I7 we enter a new dimension of complexity. This partimento is a special kind of a fugue, actually a hybrid between a fugue and a Classical sonata form. Its realization goes far beyond that of a figured (or unfigured) bass. From this point onwards, all remaining

8 Giacomo Tritto: Partimenti e Regole generali per conoscere qual numerica dar si deve a vari movimenti del Basso, Milan [I8I6]; id.: Scuola di Contrappunto ossia teorica musicale dedicata a sua maestà Ferdinando I, Milan [I8I6].

9 It is noteworthy that the partimento principle also permeates the other treatise, the Scuola di contrappunto, in form of Lezzioni and fugues. However, Tritto makes it clear that the student should realize the Lezzioni in written form, strictly following a fixed number of parts: "Farete le seguenti sei lezioni a due, a tre, ed a quattro voci." Ibid., p. 22.

10 Giorgio Sanguinetti: The Art of Partimento. History, Theory and Practice, New York 2012, pp. I07, I24.

11 See the first two Lezzioni. 
partimenti point to the development of the ability to transform sketchy notation into a rich, fully resonant texture.

In my book The Art of Partimento I use the term "sonata" for a wide array of partimenti, ranging from Pasquini to Tritto, with one caveat: that the label "sonata" is used with a very loose meaning, that is, "a partimento in which a formal articulation in two or three parts is evident."I2 However, in the case of Tritto, I narrowed the interpretation of the word "sonata" to what is currently known as "sonata form" in the Classical style. As an example, I transcribed and described in detail Lezzione 2I, also giving some hints for the realization. ${ }^{13}$ In this paper I will offer a transcription and a discussion of another Lezzione: No. 20, a sonata-rondo. ${ }^{\text {I4 }}$ The other partimenti in sonata form by Tritto are listed in the table shown as Figure r: ${ }^{15}$

$\begin{array}{lll}\text { No. } & \text { genre } & \text { HQD tppe } \\ \text { I7 } & \text { hybrid sonata-fugue } & \text { type 2 } \\ \text { I8 } & \text { sonata } & \text { type 2 } \\ \text { I9 } & \text { sonata } & \text { type 2 (with tutti/solo) } \\ 20 & \text { rondo-sonata } & \text { type 4 (with tutti/solo) } \\ \text { 2I } & \text { sonata } & \text { type 3 } \\ 22 & \text { sonata } & \text { type 3 } \\ 23 & \text { sonata } & \text { type 2 } \\ 24 & \text { concerto-sonata } & \text { type 5 } \\ \text { FI G U R E 1 Tritto's Lezzioni featuring elements } \\ \text { of Classical sonata form }\end{array}$

Tritto's Lezzione 20: form, genre, intention As I already said above, a mixture of modern and archaic ingredients is a characteristic feature of many of Tritto's partimenti. In Lezzione 20 (example I) this mixture manifests itself in the presence of extended passages in Fortspinnung within a Classical sonata-rondo form. In addition, Tritto's Lezzione 20 departs significantly from the standard sonata-rondo, as summarized in the table on page 64 (from William Caplin). ${ }^{\mathrm{I} 6}$

12 Sanguinetti: The Art of Partimento, p. 275.

13 Ibid., pp. 284-293.

14 A transcription and discussion of No. I8 appears in my paper: Partimento and Incomplete Notations in Eighteenth-Century Keyboard Music, in: Studies in Historical Improvisation. From Cantare super Librum to Partimenti, ed. by Massimiliano Guido, London/New York 20I7, pp. I49-I7I.

15 The column "H\&D type" refers to the classification of sonata types that appears in James Hepokoski and Warren Darcy: Elements of Sonata Theorp. Norms, Tppes, and Deformations in the LateEighteenth-Century Sonata, New York 2006.

16 William Caplin: Classical Form. A Theory of Formal Functions for the Instrumental Music of Hapdn, Mozart and Beethoven, New York I998, p. 235. 


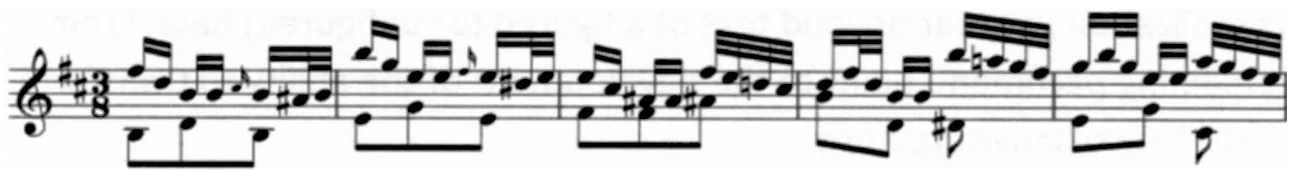

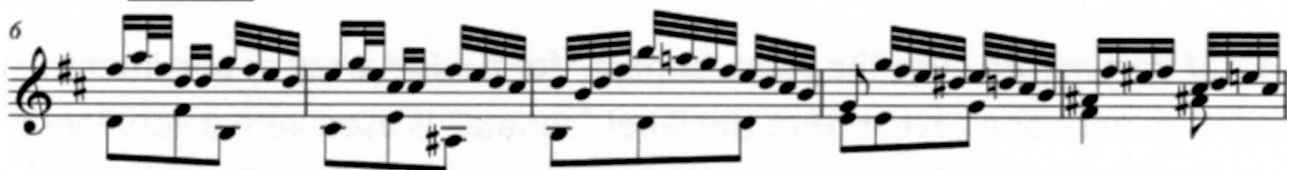

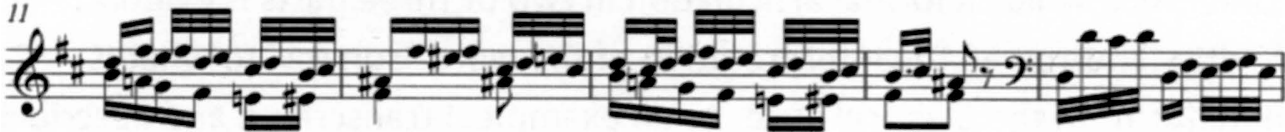

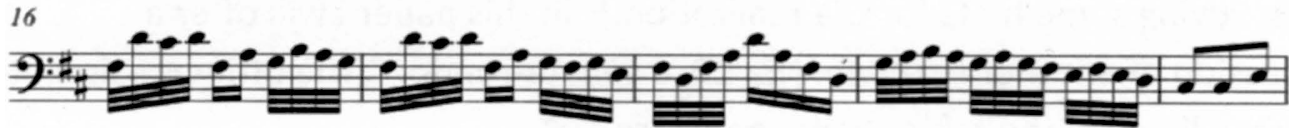
$9:$ I" 9

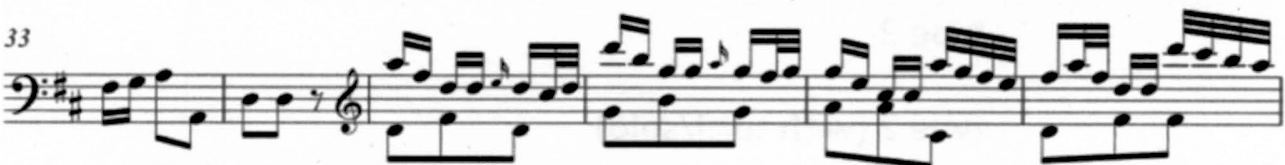

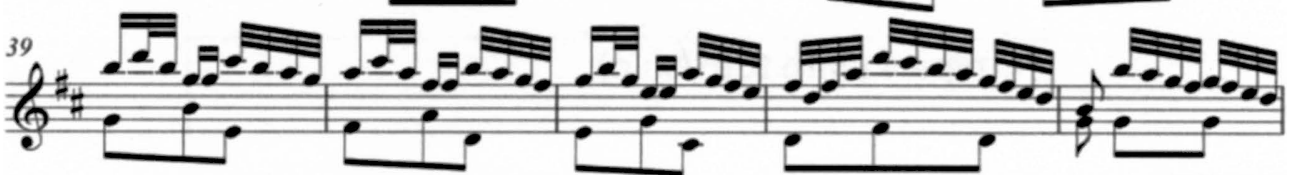

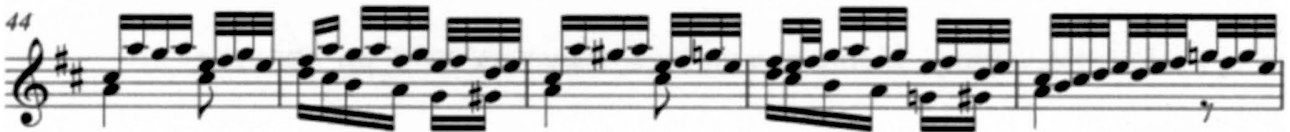

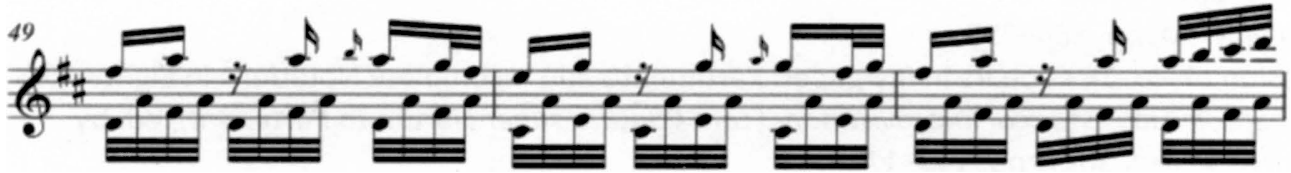


$b^{22}=0,0=\sqrt{20}=d$

$b^{25}=0$

$b^{28}=0$

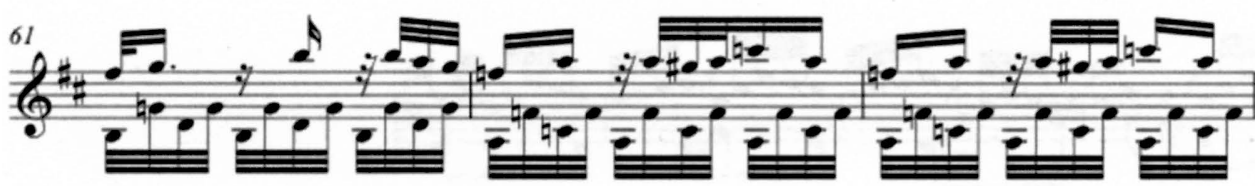

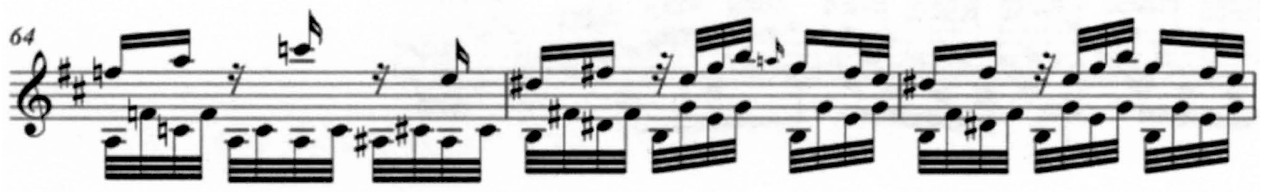

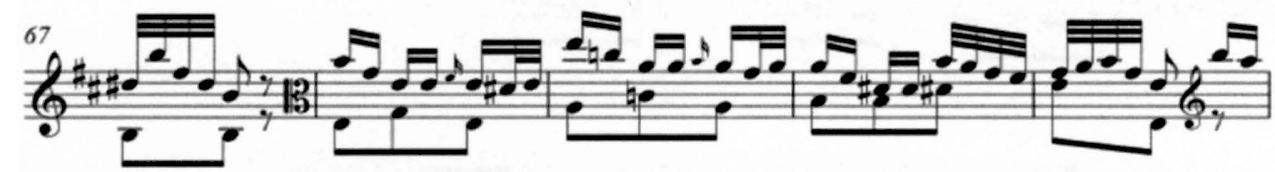
$t^{22}$

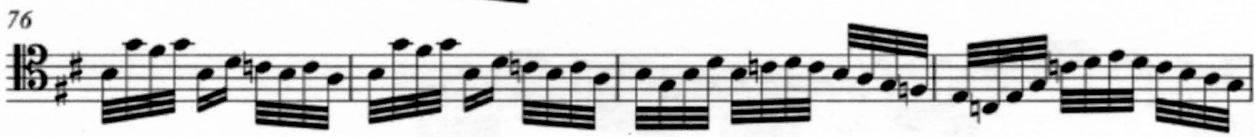

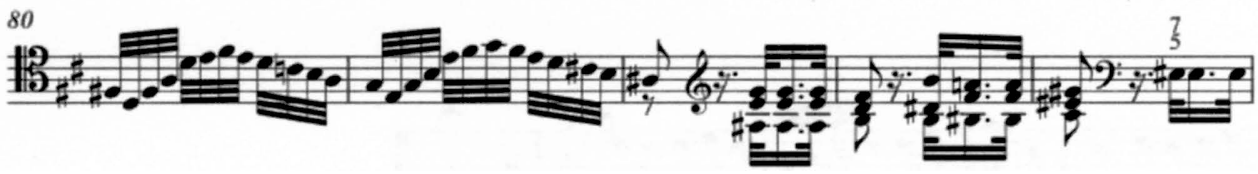


9:"

90

9:

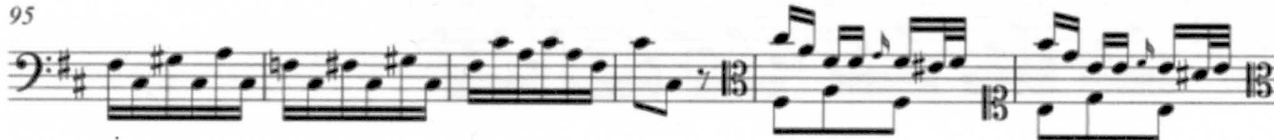
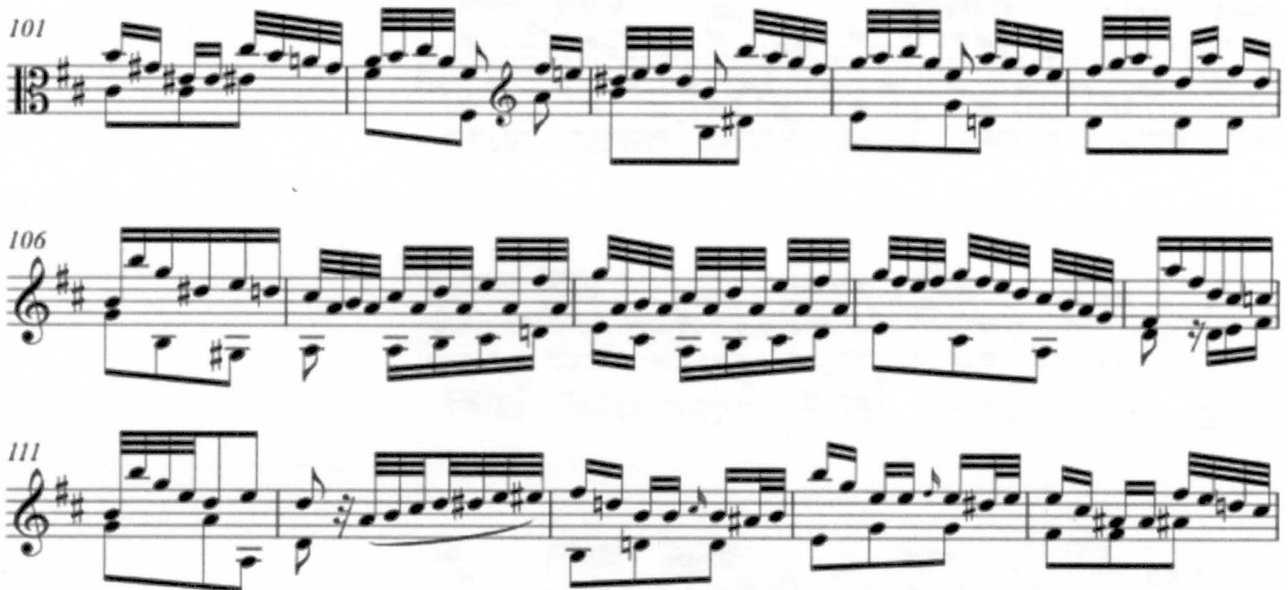

$6^{\prime \prime}+5,0$

122

9:

126

葏;

EXAM PLE 1 Giacomo Tritto: Lezzione 20 from Partimenti $e$ Regole generali 


\section{Rondo Terms Formal Functions}

refrain I (A) exposition of main theme

couplet I (B) exposition of subordinate-theme complex

refrain 2 (A) first return of main theme

couplet $2(C)$ development of interior theme

refrain 3 (A) recapitulation of main theme

couplet 3 (B) recapitulation of subordinate-theme complex I

refrain 4 (A) coda (including final return of main theme) I

FIGURE 2 Outline of a standard sonata-rondo form

(from William Caplin: Classical Form, p. 235)

The first departure concerns the tonal vagrancy of the refrains (compare figure 2 with figure 3, a formal outline of Lezzione 20). The only refrains in the main key are the first and the last: the others are in different keys (in D major, III: refrain 2) or modulate in keys other than the home key (refrain 3, from iv to VI; refrain 4/I, from v to III).

\begin{tabular}{|c|c|c|c|c|c|c|c|c|c|}
\hline Rondo & Refrain I (A) & Couplet I (B) & Refrain 2 (A) & Couplet $2(\mathrm{C})$ & Refrain $3(A)$ & Couplet 3(I) & Couplet 3(2) & Refrain $4(\mathrm{I})$ & Refrain 4 (2) \\
\hline bars & I-I4 & I5-34 & $35-48$ & $49-67$ & $68-74$ & $75-85$ & $86-98$ & $99-\mathrm{II2}$ & $\mathrm{II} 3-\mathrm{I} 30$ \\
\hline keps & $\mathrm{i}$ & III & III & III $\uparrow$ iv & iv $\uparrow \mathrm{VI}$ & $\mathrm{VI} \uparrow \mathrm{v}$ & $\mathrm{v}$ & $\mathrm{v} \uparrow \mathrm{III}$ & $\mathrm{i}$ \\
\hline \multirow[t]{2}{*}{ cadences } & V HC & I comp. cad. & V HC & V HC & no cadence & V comp. cad & V HC & I comp. cad & I comp. cad \\
\hline & MT & ST & MT first return & interior theme & MT & ST & seq. & MT & MT \\
\hline Sonata & exposition & & & & $\begin{array}{l}\text { development or } \\
\text { interior theme }\end{array}$ & recapitulation & & & coda \\
\hline
\end{tabular}

FIGURE 3 Lezzione 20, formal outline

The other departure is that couplet 3 and refrain 4 are both divided in two tonally distinct parts: in the case of couplet 3 , the two parts are separated by the most texturally salient cadence in the piece (bars 82-85). The fact that the return of the main theme in the home key occurs only at the very end of the piece, with the second part of refrain 4 , also raises doubt about labelling this section as a coda - that is, something that is not structurally essential.

Refrain 1 The main theme consists of a four-bar presentation made with a two-bar basic idea followed by a statement-response repetition $\mathrm{i}-\mathrm{iv}-\mathrm{V}-\mathrm{i}$. The presentation is followed by a five-bar sequential Fortspinnung based on a moto del basso of the kind "rising by step and falling by third" and closed by five bars of "standing on the dominant" closed by a half cadence on $\mathrm{V}$ of the home key. The transition is thus fused together with the main theme, as often happens with sonata-rondo. ${ }^{\text {I7 }}$

17 Caplin: Classical Form, p. 237. 
Couplet 1 Rather than a single subordinate theme, the first couplet contains a complex of materials: a new figure in the bass repeated through an embellished stepwise motion from I to 4 and back (I5-I8), a sequence based on moto del basso falling by fifth and rising by fourth (i9-25, followed by a cadential progression leading to a half cadence) and another sequence based on the bass suspension in series, again followed by a cadential progression leading to a compound cadence (28-34).

Refrain 2 The return of the main theme at the end of the sonata-rondo exposition is a typical feature of this form: it rounds off the exposition, hinting at the repetition of the exposition in sonata form. Here, too, Tritto departs from standard practice by setting the second refrain in the key of the major mediant, D major.

Couplet 2 According to Caplin, the "second couplet of a sonata-rondo normally takes the form of a development section or an interior theme." 8 The second case is what happens here. A new theme with a significantly contrasting texture and character takes the place of a development. Here again the tonal behaviour of this section appears to be unconventional: the interior theme begins in the same key of the previous couplet and concludes with a retransition on iv.

Refrain 3 The third refrain should demarcate the onset of the recapitulation, except in those cases when the recapitulation begins with the subordinate theme. Here the main theme returns but in a key different than the home key, namely in e minor (iv); it is followed by a short modulatory retransition leading to G major (VI), which is attained without a cadence.

Couplet 3 A radical divergence from the classical sonata-rondo occurs in the third couplet. It opens with a recapitulation of the subordinate theme, thus following standard practice. However, something unusual happens in bar 82: the 32nd-note motion in the bass (reminiscent of the sequence in bars I9-25) is interrupted by a dotted chord progression leading to a compound cadence in the key of the minor v. This dramatic break in texture divides the couplet in two parts, the second bringing new thematic material and closing with a second cadence in the same key.

Refrain 4 This fourth refrain should bring the sonata-rondo to its proper conclusion by restating the main theme in the home key for the last time. As in the previous couplet, this too is divided in two parts. The first part brings back the main theme as this sounded

18 Ibid. 
in the exposition (refrain I) in all its three components (with modifications) but avoids tonal closure: the theme is in the key of the minor $\mathrm{v}$, f-sharp minor, and modulates to the major mediant, D major. This makes it necessary to repeat the theme in the home key, and this is the task of the second part of refrain 4 . The effect, though, is that of two refrains in direct succession.

Why did Tritto write Lezzione 20? A partimento such as Lezzione 20 raises some interesting questions. What exactly is its purpose? If we were to trust the complete title of Partimenti e Regole generali, the work's aim is "to [let the reader] know which figures one must give to different bass motions". I9 In fact, the first partimenti in the series have clearly been written for this reason (as always when a partimenti collection is ordered by difficulty). But not so the more advanced ones, such as Lezzione 2o, where the harmony is often fully stated (as in the second couplet) or strongly implied (as in the refrains). This leaves open a few possibilities, the first being that this is an exemplar, that is, a formal model for advanced composition students. But even so, why did Tritto use partimento notation for an exemplar? Would it not be simpler just to write it fully down as an intavolatura? But even if we admit that this is an exemplar, what about the texture? What is immediately obvious is that, with the exception of couplet 2, when two voices are notated, only one is fully written, the other being merely sketched out. So, for example, in all refrains the upper voice is well detailed while the lower voice is not. This is obviously a consequence of partimento notation, which can use only one staff and consequently one clef at a time, thus greatly limiting the register to barely two octaves. Therefore, we might say that this partimento, like many other advanced partimenti by Tritto and other authors such as Carlo Cotumacci, is both an exemplar and a study in texture. They represent, therefore, an advanced stage in composition teaching: form and style.

Some suggestions for performance Refrains The first problem one encounters in trying to play the refrains is that the left-hand register is unfeasibly high, not allowing for a conveniently resonant rendition. However, one cannot think to solve the problem simply playing the left hand one octave lower because the result would continue to be unsubstantial. The written left-hand part needs to be developed into a complete, satisfying texture, like the one shown in Example 2.

Couplet 1 For a performer accustomed to partimenti, playing couplet I causes little or no trouble. The shift to the bass register of the partimento notation means that the part

19 "[...] per conoscere qual numerica dar si deve a vari movimenti del Basso". Tritto: Partimenti e Regole generali, title page. 

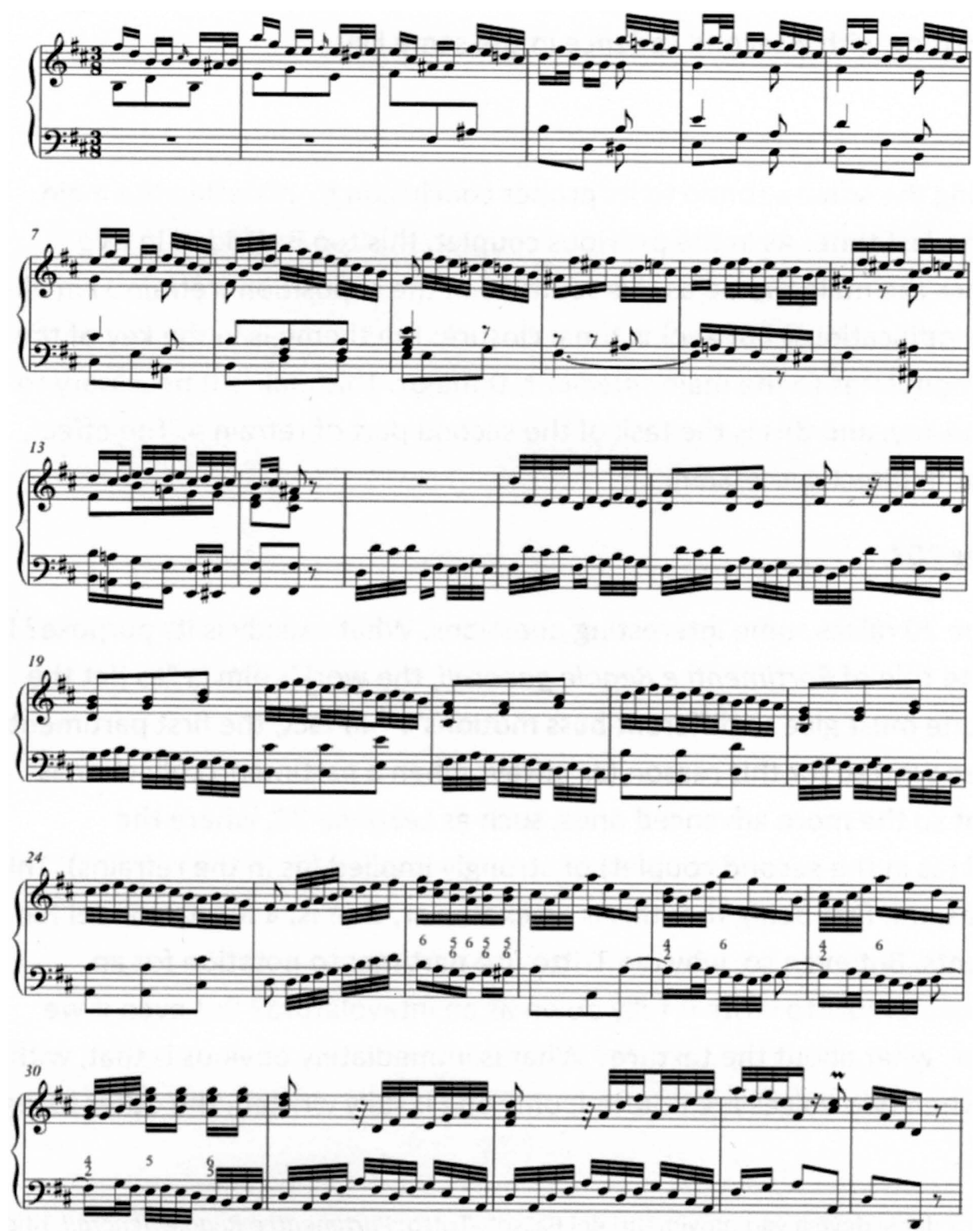

EXAM PLE 2 Lezzione 20, first refrain and first couplet realized (bars 1-34) 
to be added is now the right hand, which is usually easier to invent than the bass. In addition, the two sequences in bars I9-25 and 28-30 are quite straightforward, and the remaining bars are among the very few figured ones in the Lezzione. A possible realization is shown in Example 2. The only part of the piece that could be played as notated is perhaps couplet 2 (the "interior theme").

Conclusions Tritto's Lezzione 20, as well as his other partimenti in sonata form, offer us the possibility to reconsider and extend our notion of Classical style beyond the boundaries of Vienna - a necessity already pointed out by Anselm Gerhard fifteen years ago. $^{20}$ As we have seen, some features of this piece depart considerably from what we currently accept as Classical style: for instance, the tonal plan and the internal organization of themes and formal components. Another interesting feature is the extended usage of Fortspinnung technique, particularly in sequential passages. This may be explained on the grounds that sequences play a major role in partimento teaching but also that the Leista lineage (of which Tritto was part) perpetuated some archaic formulae well into the nineteenth century.

In conclusion, I would like to point out that a partimento such as Lezzione 20 seems to be especially tailored for practicing what I call "incomplete notation": that is, music that is only partially notated and leaves ample space for creative interventions from performers. In eighteenth-century keyboard repertoire, this kind of notation is far more common than we expect: examples of incomplete notation may be found in some Scarlatti sonatas, virtually in all of Händel's keyboard music (organ concertos included), in Paisiello's instrumental music, and in much of Mozart's keyboard repertory. As I have pointed out in another paper, partimenti such as those by Tritto can help modern performers to gain the necessary fluency to complete what the authors deliberately left void and that today is too often played in skeleton form. ${ }^{2 I}$

21 See Sanguinetti: Partimento and Incomplete Notations, p. I7r. 


\section{Inhalt}

Vorwort 7

Maria Grazia Sità Improvisation and the Rhetoric of Beginning

Lutz Felbick Der Compositor extemporaneus Beethoven als »Enkelschüler« Johann Sebastian Bachs 34

Giorgio Sanguinetti A Partimento in Classical Sonata Form by Giacomo Tritto 57

Michael Lehner »Und nun sehe man, was hieraus gemacht werden kann«. Carl Czernys Anleitung zum Fantasieren als implizite Harmonie- und Formenlehre 69

Leonardo Miucci Completing the Score.

Beethoven and the Viennese Piano Concerto Tradition $\quad 9^{8}$

Martin Skamletz Joseph Preindls Klavierfantasien als Echo von Opern- und Oratorienaufführungen in Wien um I800 II6

Martin Skamletz »Classisches Clavierspiel«. Joseph Lipavsky und das Rondeau-Fantaisie $\quad$ I37

Sonja Wagenbichler Showdown am Klavier. Zur Kultur pianistischer Wettstreite im Wien des I8. und I9. Jahrhunderts $\quad$ I64

Stephan Zirwes Formale Dispositionen in den komponierten Fantasien zur Zeit Beethovens I75

Nathalie Meidhof Variation, »Harmoniekenntniss« und Improvisation. Beethovens Fünf Variationen über das englische Volkslied »Rule Britannia« für Klavier in D-Dur (WoO 79) I92

Namen-, Werk- und Ortsregister 202

Die Autorinnen und Autoren der Beiträge $\quad 208$ 


\section{DAS FLÜCHTIGE WERK}

Pianistische Improvisation der Beethoven-Zeit •

Herausgegeben von Michael Lehner, Nathalie Meidhof

und Leonardo Miucci unter redaktioneller

Mitarbeit von Daniel Allenbach 


\section{MUSIKFORSCHUNG DER \\ Hochschule Der KÜnste Bern \\ Herausgegeben von Martin Skamletz \\ und Thomas Gartmann}

Band 12 
0 Dieses Buch ist in gedruckter Form im Juli 20I9 in erster Auflage in der Edition Argus in Schliengen/Markgräflerland erschienen. Gestaltet und gesetzt wurde es im Verlag aus der Seria und der SeriaSans, die von Martin Majoor im Jahre 2000 gezeichnet wurden. Gedruckt wurde es auf Eos, einem holzfreien, säurefreien, chlorfreien und alterungsbeständigen Werkdruckpapier der Papierfabrik Salzer im niederösterreichischen Sankt Pölten. Das Vorsatzpapier Caribic cherry wurde von Igepa in Hamburg geliefert. Rives Tradition, ein Recyclingpapier mit leichter Filznarbung, das für den Bezug des Umschlags verwendet wurde, stellt die Papierfabrik Arjo Wiggins in Issyles-Moulineaux bei Paris her. Das Kapitalband mit rot-schwarzer Raupe lieferte die Firma Dr. Günther Kast aus Sonthofen im Oberallgäu, die auf technische Gewebe und Spezialfasererzeugnisse spezialisiert ist. Gedruckt und gebunden wurde das Buch von der Firma Bookstation im bayerischen Anzing. Im Internet finden Sie Informationen über das gesamte Verlagsprogramm unter www.editionargus.de, zum Institut Interpretation der Hochschule der Künste Bern unter www.hkb.bfh.ch/interpretation und www.hkb-interpretation.ch. Die Deutsche Nationalbibliothek verzeichnet diese Publikation in der Deutschen Nationalbibliografie; detaillierte bibliografische Daten sind im Internet über www.dnb.de abrufbar. (C) der zeitgleich erschienenen digitalen Version: die Autorinnen und Autoren, 2019. Dieses Werk ist lizenziert unter einer Creative Commons Namensnennung-Nicht kommerziell 4.0 International Lizenz (CC BY-NC 4.0). Dor: https://doi.org/I0.26045/kp64-6I76 ISBN 978-3-93I264-92-5 